\title{
Characterization of Ar-Rassafeh Badyieh area (Area-2), Syria by using the airborne gamma-ray spectrometric and fractal modelling techniques
}

\author{
Jamal ASFAHANI \\ Atomic Energy Commission, P.O. Box 6091, Damascus, Syria \\ e-mail: cscientific@aec.org.sy
}

\begin{abstract}
The available aerial gamma-ray spectrometric data of Ar-Rassafeh Badyieh area (Area-2) are used herein for geological interpretations and mapping purposes. Those data are interpreted by the concentration-number (C-N) fractal modelling technique, with the use of log-log graphs. According to C-N model, different radioactive ranges of TC, $\mathrm{eU}$, eTh, and $\mathrm{K}$ have been isolated. Those ranges are thereafter used to characterize the lithological outcrops in the study area. The radioactive signatures of all the outcrops in Area-2 have been discussed and documented through establishing the C-N maps of TC, $\mathrm{eU}$, eTh, and $\mathrm{K}$, and benefiting of the available geological map. The C-N fractal modelling technique proves its efficacy, where radioactive and lithological boundaries of outcrops are in concordance. The case study presented in this paper shows the importance and the role of airborne gamma-ray spectrometric and fractal modelling techniques to support the geological mapping and the interpretations in geological context, particularly when the study region is rugged and difficult to be accessed.
\end{abstract}

Key words: fractal modelling technique, aerial gamma-ray spectrometry survey, AlRassafeh area, Syria

\section{Introduction}

The airborne gamma-ray spectrometric survey has been essentially oriented towards defining radioactive anomalies related to uranium mineralization (International Atomic Energy Agency, 1988). It can also be employed to investigate the other useful minerals and sometimes the subsurface hydrocarbon accumulations (Selley, 1998). The gamma-ray spectrometric data have also been applied with variable degrees of success to the mapping of lithological units. The success of such a mapping depends on several factors; the most important one is the contrast in radioelement content between lithological assemblages. The geological mapping is based on the assumption that the absolute and relative concentrations of the radioelements vary measur- 
ably and significantly with lithology. Integrated interpretation, altogether with aerial photograph, satellite imagery and other airborne geophysical data sets, allows exploiting the complementary geological information and enables the radioelement distributions to be studied in a structural geologic and geomorphologic context.

Airborne gamma-ray spectrometry surveying also offers a promising tool for lithofacies mapping of sedimentary basins as evaporates, carbonates, sandstones and shales. Those lithofacies can usually be differentiated in their radioelement content, because clastic sediments often reflect the radioelement compositions of the provenance source materials (Dickson and Scott, 1997). Saunders et al. (1994) have already defined the typical radioelement concentrations over those mentioned lithofacies and indicated their importance for petroleum exploration.

The statistical factor analysis technique (SFAT) has been recently applied on aerial gamma-ray spectrometric related to the Ar-Rassafeh Badyieh area (Area-2), Syria to establish a lithological scored map (Asfahani et al., 2018). This lithological scored map is an important tool for geological mapping and allows the different isolated sectors to be characterized and interpreted geologically and radioactively.

This paper deals with the application of the concentration-number $(\mathrm{C}-\mathrm{N})$ fractal modelling technique as a suitable tool to interpret the aerial gammaray spectrometric data of Ar-Rassafeh Badyieh area (Area-2), Syria in terms of geological mapping for evaluating with details of the total radioactivity (TC) in Ur, equivalent uranium (eU) in ppm, equivalent thorium (eTh) in ppm, and potassium $(\mathrm{K})$ in \% signatures of the outcrop rocks in the study area. The reasons behind using the fractal modelling technique are the weakness and disadvantage points that characterize the traditional statistical techniques. In fact, those conventional techniques based on normal or log-normal distribution do not take into consideration the shape, extent and magnitude of radioactive anomalous areas (Rafiee, 2005; Afzal et al., 2010). Moreover, geological and geochemical conditions do not have any influence on the geophysical anomaly separation from background (Reimann et al., 2005). Traditional Euclidean geometry cannot consequently explain and examine the natural processes with their different populations, especially geo-related sciences (Davis, 2002).

The C-N fractal modelling technique was recently used by Asfahani (2017) 
to differentiate among different kinds of basalt in Southern Syria through interpreting nuclear and electrical well logging. The same fractal technique was also used to interpret the aerial gamma-ray spectrometric for separating uranium anomalies from background in Area-3, and for characterizing the radioactive heat production of Area-1 (Asfahani, 2018a, 2018b).

The Area-2 study region is particularly a very rugged terrain, where we ignore and have only a little information about its geology. A detailed field geological investigations are therefore extremely required. Such needed geological works are not actually an easy task to be carried out in the near future, due to the present Syrian difficult conditions. The aerial gamma-ray spectrometric survey and its available data is therefore a powerful tool, and can be used to characterize geologically the study region and to determine the different radioactive ranges of $\mathrm{TC}, \mathrm{eU}$, eTh, and $\mathrm{K}$ signatures related to different lithological facies. The application of the aerial gamma-ray spectrometry technique with the $\mathrm{C}-\mathrm{N}$ fractal modelling technique in the study Area-2 replaces temporarily the field geological works, and remedies consequently the scarcity of geological information of the mentioned region.

\section{Object of study}

The main objectives of this paper are therefore the following:

1. To interpret the available aerial gamma-ray spectrometry data related to the Area- 2 by $\mathrm{C}-\mathrm{N}$ fractal modelling technique.

2. To isolate different radioactive ranges of $\mathrm{TC}$, eU, eTh, and $\mathrm{K}$, by using the $\mathrm{C}-\mathrm{N}$ model, and establish the different $\mathrm{C}-\mathrm{N}$ maps accordingly.

3. To determine the radioactive signatures of the outcrop rocks in the study area for the $\mathrm{TC}$, eU, eTh, and $\mathrm{K}$.

4. To compare the obtained interpretative aerial gamma-ray spectrometry results with the available geological map of the study area to draw definitive conclusions.

\section{Area of study}

International Atomic Energy Commission and Risø National Laboratory conducted in Syria in 1987 the airborne gamma-ray spectrometric surveys 
during SYR/86/005 project (Risø, 1987; Jubeli, 1990). Those surveys covered the following areas (Fig. 1a) (Asfahani et al., 2018):

1. The Syrian Desert (Area-1) (7189 line $\mathrm{km}$ at $4 \mathrm{~km}$ line spacing).

2. Ar-Rassafeh Badyieh (Area-2) (2240 line $\mathrm{km}$ at $4 \mathrm{~km}$ line spacing).

3. The Northern Palmyrides (Area-3) (1600 line $\mathrm{km}$ at $3 \mathrm{~km}$ line spacing).

The total radiometric TC (Ur) map of the covered three mentioned areas is shown in Fig. 1b (Asfahani et al., 2018).

The present paper is oriented towards geological mapping of the outcrop rocks of Ar-Rassafeh Badyieh (Area-2), through determining the different radioactive ranges ( $\mathrm{TC}$, eU, eTh, and $\mathrm{K}$ ) by the application of the $\mathrm{C}-\mathrm{N}$ fractal modelling technique, that could be used as radioactive signatures for

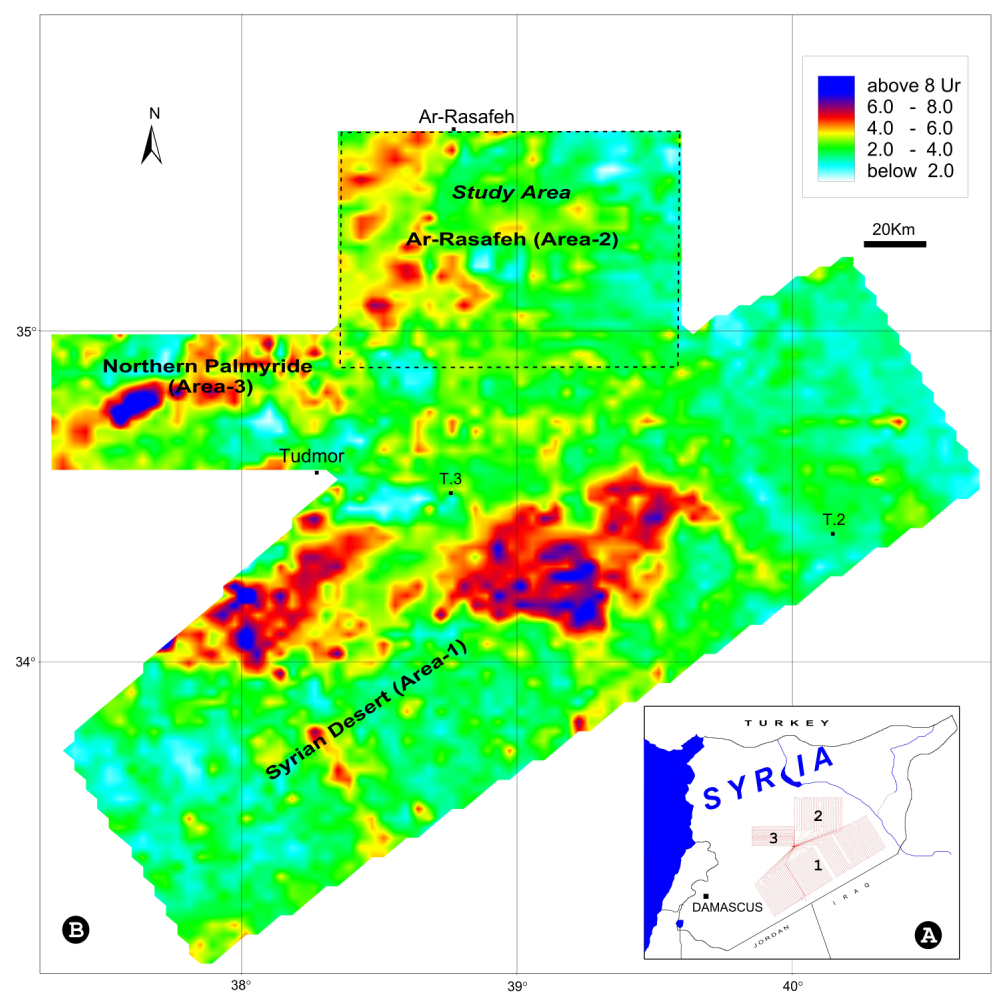

Fig. 1: (a) Total areas covered by the airborne gamma-ray spectrometry technique in Syria. (b) Radiometric map of TC resulting from gamma-ray spectrometric survey. 
the lithological outcrop rocks. Fig. 2 shows the geology of the study Area-2 as described by Asfahani et al. (2018). Readers are advised to consult the paper of Asfahani et al. (2018) for more geological details about the study region.

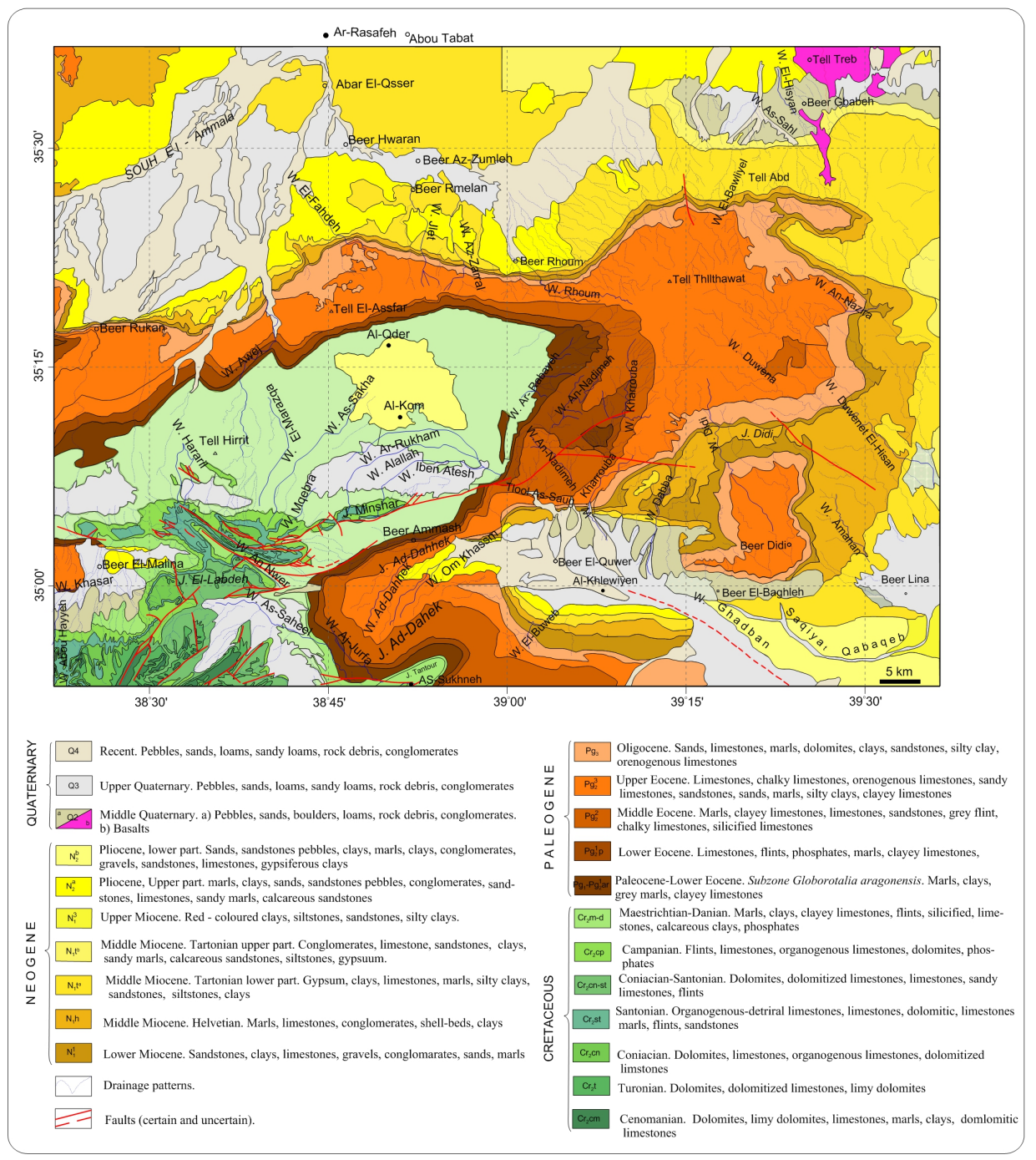

Fig. 2: Geological map of Ar-Rassafeh Badyieh area (Area-2) (Asfahani et al., 2018). 


\section{Methods of study}

\subsection{Aerial gamma-ray spectrometric technique}

An airborne gamma-ray survey was carried out during 1987, over the ArRassafeh Badyieh area (Area-2) situated north of Syrian desert in the region between the northern Palmyrides in the south-west and the Euphrates in the northern and east. Area- 2 was covered by 28 north-south oriented aerial survey lines. Those lines are $80 \mathrm{~km}$ long, and spaced by $4 \mathrm{~km}$, Fig. 1a. The typical survey speed was of $120 \mathrm{~km} / \mathrm{hr}$ in a nominal survey, and the height was of 30 meters. A system of a compact, lightweight, four-channel gammaray spectrometer, (GAD-6, Scintrex, Canada), with a detector of 12.5 letters $\mathrm{NaI}(\mathrm{Tl})$ volume had been used to conduct this aerial survey. The energy windows used in the four-channel gamma-ray spectrometer are shown in Table 1. The system calibration took place at the calibration pads at the Dala airport in Sweden (Risø, 1987). An IGI Loran-C navigation system was used to provide efficient flight path control. Potassium, uranium, thorium, and total gamma-ray counts were recorded over one-second intervals and stored on a data tape together with the actual distance to the ground measured with a radar altimeter.

The raw data were corrected for background effects and the applicable interchange, Compton corrections. In addition, the exponential attenuation factors for height corrections were established (Risø, 1987).

Table 1. Range of energy with spectral windows used in the airborne survey.

\begin{tabular}{ccc}
\hline window & $\begin{array}{c}\text { airborne radiometric } \\
\text { survey }(\mathrm{MeV})\end{array}$ & $\begin{array}{c}\text { dominant } \\
\text { radioisotope }\end{array}$ \\
\hline potassium & $1.38-1.56$ & $\mathrm{~K}^{40}$ \\
uranium & $1.66-1.90$ & $\mathrm{Bi}^{214}$ \\
thorium & $2.44-2.77$ & $\mathrm{Tl}^{208}$ \\
total count & $0.40-2.77$ & - \\
\hline
\end{tabular}

\subsection{Concentration-number $(\mathrm{C}-\mathrm{N})$ fractal modelling technique}

Fractal geometry is proposed by Mandelbrot (1983) to discuss and explain processes in nature. Different fractal analysis methodologies have been al- 
ready proposed and applied in different geosciences domains, especially geophysical exploration since 1980s, such as Power Spectrum-Area (S-A; Cheng et al., 1999), and Power Spectrum-Volume (S-V; Afzal et al., 2012; Afzal et al., 2017b), Concentration-Volume (C-V; Afzal et al., 2011), ConcentrationArea (C-A; Cheng et al., 1994), and Concentration-Number (C-N; Hassanpour and Afzal, 2013).

Log-log plots are used while applying fractal models, where the straight line segments fitted the log-log graph have some break threshold points (Zuo 2011; Wang et al., 2011; Mohammadi et al., 2013).

The present paper proposes the application of the C-N fractal modelling technique as a suitable tool to interpret the available aerial gamma-ray spectrometric data related to Ar-Rassafeh Badyieh area (Area-2), Syria. This fractal technique is oriented towards isolating different radioactive ranges of $\mathrm{TC}$, eU, eTh and $\mathrm{K}$, and radioactively characterizing the outcrop rocks in term of Area-2 geological mapping.

The superiority of the fractal modelling technique is proven because of using all the available data and considering their spatial relations with each other (Afzal et al. 2010; Carranza, 2008; Cheng et al., 1994; Hassanpour and Afzal, 2013; Li et al., 2003; Wang et al., 2008; Heidari et al., 2013; Afzal et al., 2011; 2012; 2013; 2016; 2017a,b; Sadeghi et al., 2012; Rahmati et al., 2015; Meigoony et al., 2014; Nazarpour et al., 2015; Cheng 2007; Hosseini et al., 2015).

The Concentration-Number (C-N) fractal model is expressed by the following equation:

$N(\geq \rho)=F \rho^{-D}$,

where $\rho$ denotes the treated geophysical parameter values, which are in this case study a total radioactivity (TC), equivalent uranium (eU), equivalent thorium (eTh), and potasium (K\%), $N(\geq \rho)$ denotes the cumulative number of the treated geophysical data, which are the cumulative number of total radioactivity (CNTC), the cumulative number of equivalent uranium $(\mathrm{CNeU})$, the cumulative number of equivalent thorium $(\mathrm{CNeTh})$, and the cumulative number of potasium $(\mathrm{CNK} \%)$, with the geophysical parameter values greater than or equal to $\rho, F$ is a constant and $D$ is the scaling exponent or fractal dimension of the distribution of geophysical parameter values. 


\section{Results and discussion}

The multifractal modelling technique with adapting concentration-number (C-N) model is developed and applied herein to analyse the behaviour of the TC, eU, eTh, and $\mathrm{K} \%$ parameters in the Area-2. Table 2 represents the main statistical characteristics of $\mathrm{TC}$, eU, eTh, and $\mathrm{K} \%$.

Table 2. Statistical characteristics of the radioactive variables in Area-2.

\begin{tabular}{ccccc}
\hline Variable & TC & K $(\%)$ & $\mathrm{eU}(\mathrm{ppm})$ & $\mathrm{eTh}(\mathrm{ppm})$ \\
\hline Case number & 61712 & 61712 & 61712 & 61712 \\
Min & 0.23 & 0.02 & 0.16 & 0.16 \\
Max & 17 & 0.85 & 13.61 & 9.28 \\
$\bar{X}$ & 4.55 & 0.26 & 1.59 & 3.39 \\
$\sigma$ & 1.36 & 0.09 & 0.95 & 1.15 \\
$\mathrm{CV}$ & 29.9 & 34 & 59.75 & 33.9 \\
$\bar{X}+2 \sigma$ & 7.27 & 0.44 & 3.50 & 5.69 \\
\hline
\end{tabular}

The advantages of using the multifractal modelling technique and its superiority in comparison with the traditional statistical technique are discussed above, which justify its application in such a quantitative interpretation.

The C-N log-log plots are proposed and applied to characterize the four radioactive parameters ( $\mathrm{TC}$, eU, eTh and $\mathrm{K} \%$ ) obtained by aerial gammaray spectrometry in Area-2. The concept of break point is adapted and used herein as a lithological boundary between different kinds of outcrop rocks to indicate the passage from a specific lithology to another different one.

Log-log plot of $N(\geq \rho)$ versus $\rho(\mathrm{TC}$, eU, eTh and $\mathrm{K})$ shows the straight line segments with the different slopes $-D$ corresponding to different radioactivity intervals. The break points of those line segments are considered as thresholds. The selection of break points as the threshold values appears to be an objective decision due to the different geophysical populations, which are recognized by different segments in the C-N log-log plot. The geophysical populations of those treated parameters are therefore divided and established based on linear segments and break points in the log-log plots. 


\subsection{Total radioactivity $\mathrm{TC}(\mathrm{Ur})$}

Based on the C-N log-log plot shown in Fig. 3, the total radioactivity $\log (\mathrm{TC})$ shows four threshold break points C1, C2, C3 and C4 at 0.54, $0.79,0.94$ and 1.05 respectively.

The $\log (\mathrm{TC})$ values indicate total radioactivity of $3.47,6.16,8.71$, and 11.22 Ur respectively. Those four break points correspond to five natural radioactivity ranges as follows: The first range is less than $3.47 \mathrm{Ur}$, the second range is between 3.47 and $6.16 \mathrm{Ur}$, the third range is between 6.16 and $8.71 \mathrm{Ur}$, the fourth range is between 8.71 and $11.22 \mathrm{Ur}$, and the fifth range is bigger than $11.22 \mathrm{Ur}$.

According to those five TC natural radioactivity ranges, a map of the TC distributions is established for the study Area-2 region as shown in Fig. 4.

The range of below 3.47 Ur is belonging in some parts of Area-2 to Middle Quaternary of basalts, to Lower Miocene of sandstones, clays, limestones, gravels, conglomerates and sands, and to the Cenonian of dolomites, limy dolomites, marls, clays, and dolomitic limestones. The last range of above 11.20 Ur is removed from interpretation because it represents punctual values. The rest three ranges are therefore important and could be interpreted in lithological context as follows:

- The range of 3.47 to 6.16 Ur represents reef marine calcareous facies that change gradually to continental (Paleogene-Neogene), passing through

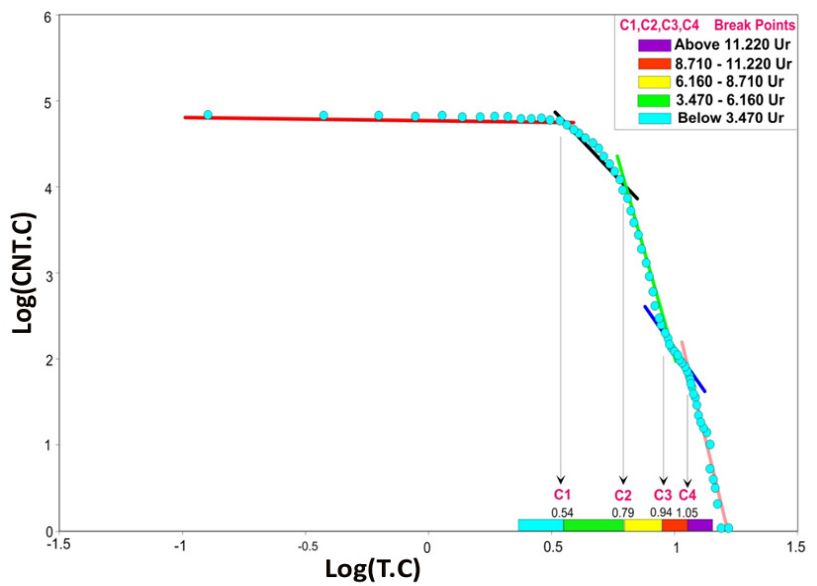

Fig. 3: Log-log plot of total radioactivity TC in the Area-2. 


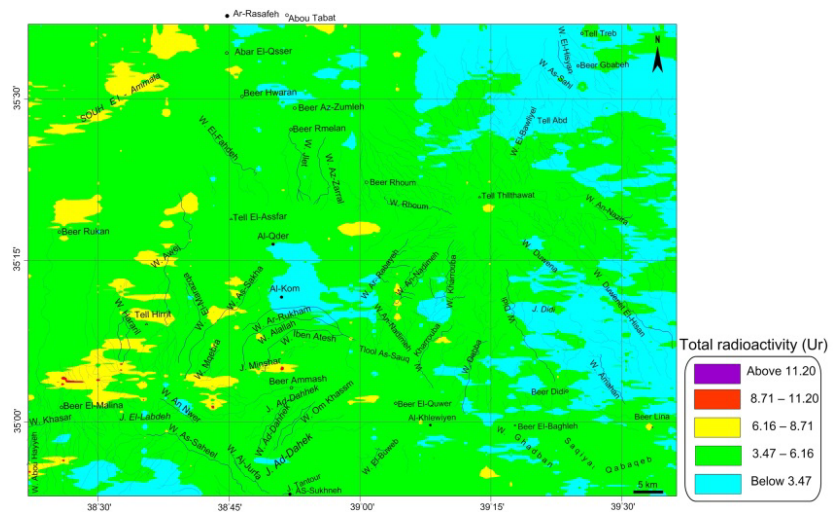

Fig. 4: Natural total radioactivity TC map derived by the C-N fractal modelling in ArRassafeh Badyieh area (Area-2), Syria.

lagoon to coastal facies of sandstones and various sands.

- The range of 6.16 to 8.71Ur represents Quaternary flood surfaces composed of evaporates and alluvium and gathered deposits from the erosion materials of the adjoining rocks, which are usually deposited uncomfortably over the older rocks.

- The range of 8.71 to 11.20 Ur represents Upper Cretaceous rocks outcropping along the faulted zones, which are limestone, calcareous-dolomite and phosphates beds alternating with flints.

\subsection{Equivalent uranium eU (ppm)}

Based on the C-N log-log plot presented in Fig. 5, the equivalent uranium $\log (\mathrm{eU})$ shows also four threshold break points $\mathrm{C} 1, \mathrm{C} 2, \mathrm{C} 3$, and $\mathrm{C} 4$ at 0.22 , $0.5,0.63$, and 1 respectively. The $\log (\mathrm{eU})$ values indicate an equivalent uranium eU of 1.66, 3.16, 4.26, and 10 respectively. Those four break points correspond to five uranium ranges as follows: The first range is less than 1.66 , the second range is between 1.66 and 3.16, the third range is between 3.16 and 4.26, and the fourth range is between 4.26 and 10 and the fifth range is bigger than 10 .

According to those five eU ranges, a map of the eU distributions is established for the study Area-2 region as shown in Fig. 6 . 


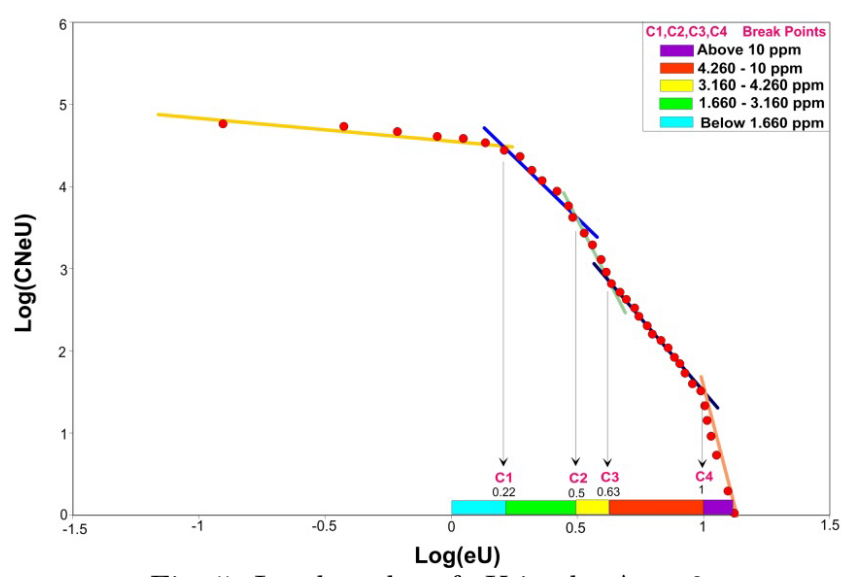

Fig. 5: Log-log plot of eU in the Area-2.

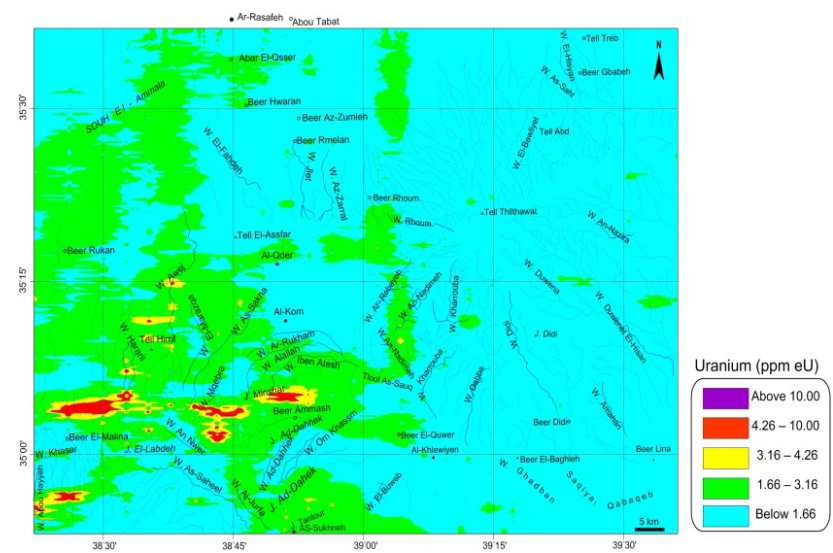

Fig. 6: Equivalent uranium eU map derived by the C-N fractal modelling in Ar-Rassafeh Badyieh area (Area-2), Syria.

The low range of below $1.66 \mathrm{ppm}$ represents the most parts of Area2. The different ages of Neogene, the Quaternary, and the different ages of Paleogene are characterized by equivalent uranium (eU) of bellow 1.66 ppm. One can match between Fig. 6 and Fig. 2 to follow the geological descriptions of the areas related to this low eU radioactive range. The last range of above $10 \mathrm{ppm}$ is removed from interpretation because it represents punctual values. The rest three ranges are therefore important and could be interpreted in lithological context as follows: 
- The range of 1.66 to $3.16 \mathrm{ppm}$ represents surfaces flooding formations that uncomfortably overlie the Cretaceous rocks.

- The range of 3.16 to 4.26 ppm represents Calcareous rocks, phosphates, calcareous dolomites and flints.

- The range of 4.26 to $10 \mathrm{ppm}$ represents Outcropped calcareous phosphates rocks, calcareous, dolomites along the faulted zones (calcareous breccias - alternating with of phosphates and flints).

The eU ranges established by $\mathrm{C}-\mathrm{N}$ approach and the determined breakpoints indicate an obvious passage from a specific lithology to another different one. The multifractal technique with $\mathrm{C}-\mathrm{N}$ model is consequently capable to reflect the lithology of the study Area-2, where a strong correspondence and coincidence between both geological and radioactive boundaries exists.

\subsection{Equivalent thorium eTh (ppm)}

Based on the C-N log-log plot shown in Fig. 7, the equivalent thorium $\log (\mathrm{eTh})$ indicates three threshold break points $\mathrm{C} 1, \mathrm{C} 2$, and $\mathrm{C} 3$ at 0.342 , 0.549 and 0.793 respectively. The $\log (\mathrm{eTh})$ values indicate an eTh of 2.20, 3.54 , and 6.21 respectively. The three indicated break points correspond to four eTh ranges as follows: The first range is less than 2.20 , the second range is between 2.20 and 3.54 , the third range is between 3.54 and 6.21 , and the fourth range is bigger than 6.21 .

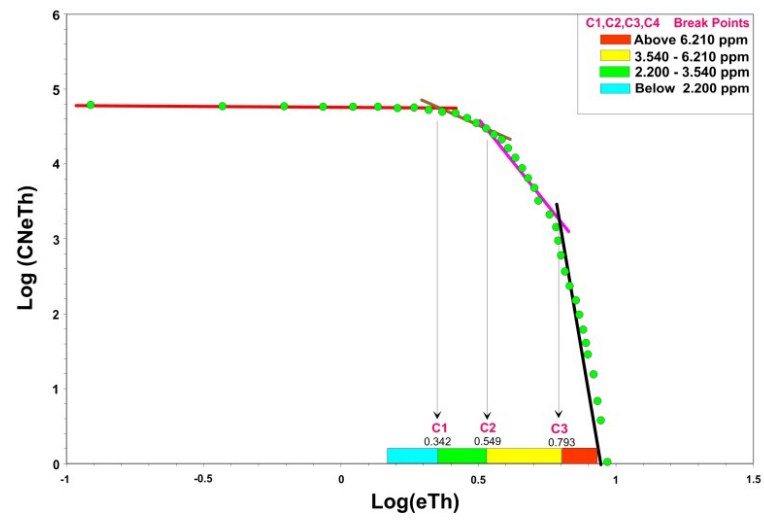

Fig. 7: Log-log plot of eTh in the Area-2. 
According to those four eTh ranges, a map of the eTh distributions is established for the study Area-2 region as shown in Fig. 8.

The first range of below $2.20 \mathrm{ppm}$ represents the background. The Cretaceous of Cenomanian and Turonian ages, The Neogene of Pliocene lower part, and Middle and lower Miocene are characterized by eTh of below 2.20 ppm. The matching between Fig. 8 and Fig. 2 allows to follow the geological descriptions of the areas related to this low eTh radioactive range. The rest three ranges are of geological significance and could be interpreted in lithological context as follows:

- The range of 2.20 to $3.54 \mathrm{ppm}$ represents surfaces of tidal formations intervened by some deltaic zones and shallow sub/ littoral continental shelf deposits (sandy limestone, clayey calcareous, and sandy silt).

- The range of 3.54 to $6.21 \mathrm{ppm}$ represents shallow marine deposits dominated by clayey silt facies (calcareous, clays, silt).

- The range of above $6.21 \mathrm{ppm}$ represents in situ formation of terrestrial spotty soil deposits.

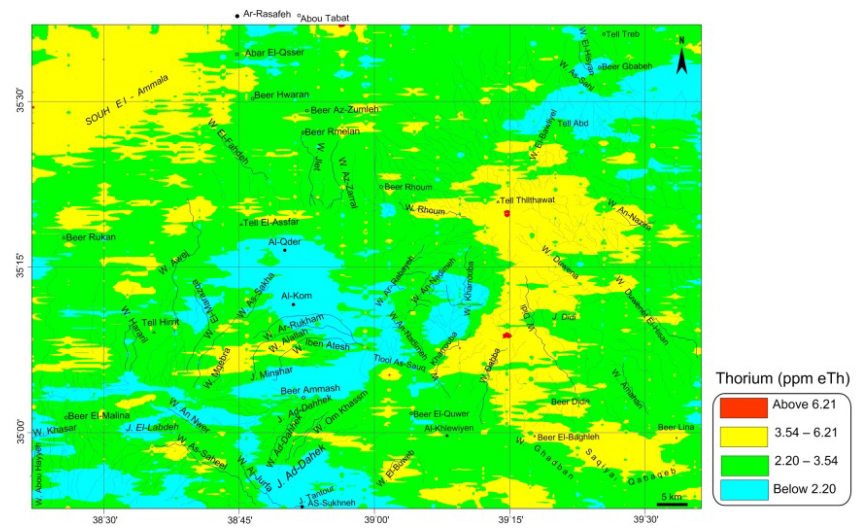

Fig. 8: Equivalent thorium eTh map derived by the C-N fractal modelling in Ar-Rassafeh Badyieh area (Area-2), Syria.

\subsection{Potassium K (\%)}

Based on the C-N log-log plot shown in Fig. 9, the potassium log $(\mathrm{K} \%)$ indicates four threshold break points $\mathrm{C} 1, \mathrm{C} 2, \mathrm{C} 3$ and $\mathrm{C} 4$ at $-0.696,-0.59$, -0.347 and -0.15 respectively. The $\log (\mathrm{K} \%)$ values indicate a $\mathrm{K} \%$ of 0.20 , 
$0.257,0.449$ and 0.710 respectively. The above four break points correspond to five $\mathrm{K} \%$ ranges as follows: The first range is less than 0.20 , thesecond range is between 0.20 and 0.257 , the third range is between 0.257 and 0.449 , the fourth range is between 0.449 and 0.710 and the fifth range is bigger than 0.710 .

According to those five $\mathrm{K} \%$ ranges, a map of the $\mathrm{K} \%$ distributions is established for the study Area-2 region as shown in Fig. 10.

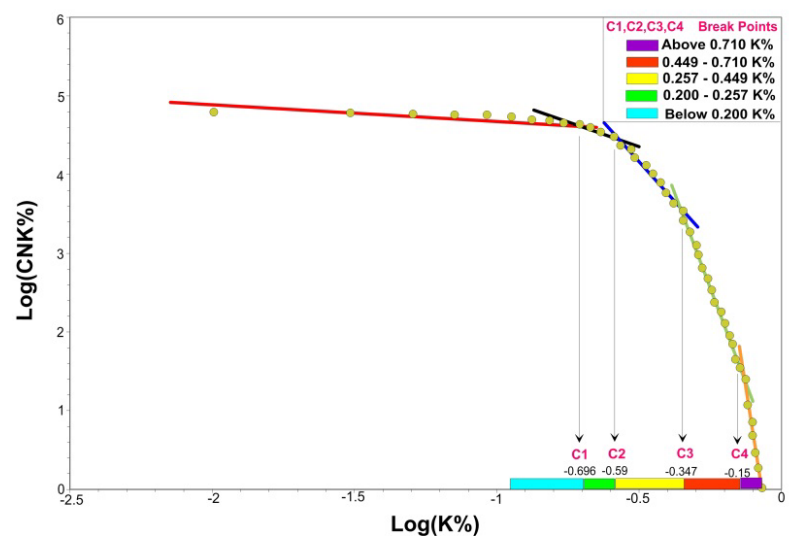

Fig. 9: Log-log plot of $\mathrm{K} \%$ in the Area-2.

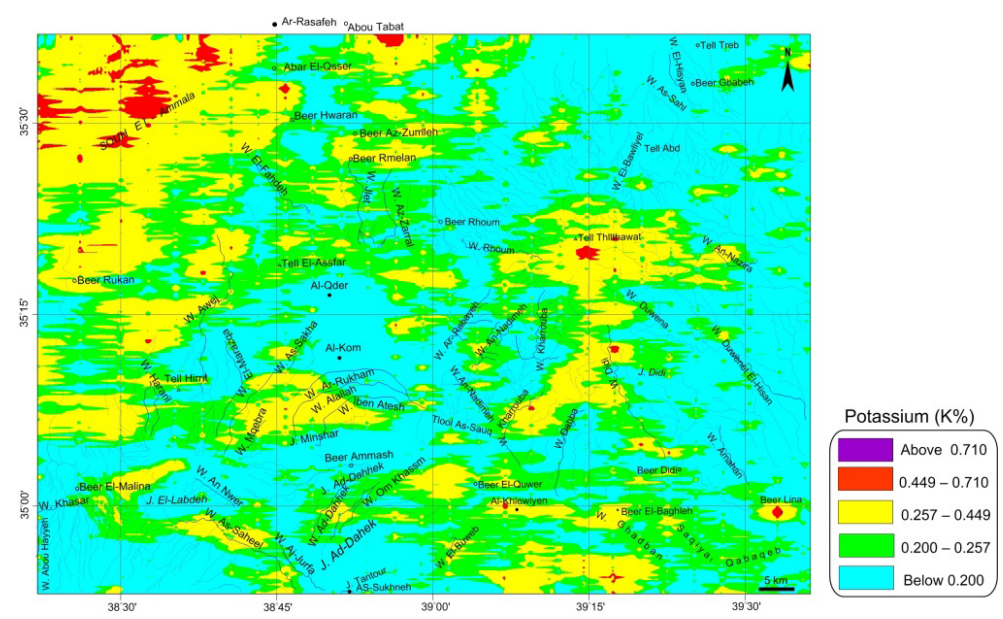

Fig. 10: Potassium K\% map derived by the C-N fractal modelling in Ar-Rassafeh Badyieh area (Area-2), Syria. 
The first range of below $0.20 \%$ represents the background. The Cretaceous of Cenomanian and Turonian ages, the Neogene of lower part age, and the upper Quaternary are characterized by a K\% of below $0.20 \%$. The matching between Fig. 10 and Fig. 2 allows to follow the geological descriptions of the areas related to this low $\mathrm{K}$ radioactive range. The last range of above $0.7 \%$ is removed from interpretation because it represents punctual values. The following three ranges are geologically important, and could be interpreted in lithological context as follows:

- The range of 0.20 to $0.257 \%$ represents the boundaries of gradual deposits from Paleocene-Neogene, that are covered by Quaternary formations of floods, conglomerates, evaporates, calcareous dolomites, sandy calcareous and clayey calcareous.

- The range of 0.257 to $0.449 \%$ represents shallow marine deposits, marine shelf (Paleocene) that changes gradually to continental deposits (Neogene), passing throughout lagoon and tidal facies of marl, silty clay, calcareous clayey, calcareous sandy, and sands.

- The range of 0.449 to $0.710 \%$ represents marine deposits (Paleogene) that are dominated by calcareous clays and sandy clays.

The log-log accumulative distributions presented and documented for the four studied parameters (TC, eU, eTh, and K\% ), (Figs. 3, 5, 7, and 9) show clearly the different line segments, characterized each by a specific slope. Each line segment presents an isolated radioactive level, and reflects a specific lithological outcrops.

The breakpoints shown in the different log-log of the studied parameters represent in this specific $\mathrm{C}-\mathrm{N}$ multi fractal modelling application a kind of radioactivity boundaries and indicate the passage from radioactive lithological level to another different one. Each radioactive level reflects a distinguished lithological process and is strongly attached to a specific outcrop rocks. This observed and clear attachment between lithology and radioactivity is one of the advantages of the multifractal C-N approach applied in this research.

The case study presented in this paper obviously shows an example of the role of airborne gamma-ray spectrometric survey in geological mapping, by supporting and providing with additional geological knowledge, particularly in the rugged geology. The $\mathrm{C}-\mathrm{N}$ fractal modelling technique is also a smart powerful tool to interpret the airborne gamma-ray spectrometric 
data, where the different outcrops and lithologies in the study region are well differentiated.

\section{Comparison between the statistical factor analysis tech- nique (SFAT) and (C-N) fractal modelling technique}

The two mentioned techniques (SFAT) and (C-N) are completely different from mathematically point of view. However, the combination of their results largely contributes in better understanding the geology of the study region, particularly in the rugged and complex geology, such as the case study of Area-2.

The SFAT applied already in a previous research is essentially based on determining the main rotated factors that could be interpreted geologically. SFAT is oriented towards transferring basically the geological map of the study region to a lithological scored map as done by Asfahani et al. (2018). The resulting lithological scored map contained nine different lithological units, that were described and characterized according to different determined factors F1, F2, and F3 (Asfahani et al., 2018). The results obtained by this SFAT technique allow a reasonable geological interpretation to be done through understanding the mutual relations among the different lithological scored units.

The fractal C-N technique applied in this paper is differently oriented towards dealing only with the available original radioactive maps of TC, $\mathrm{eU}$, eTh, and $\mathrm{K} \%$ to determine the radioactive ranges for every studied parameter. It is essentially based on the threshold break points concept. The determination of those break points on the log-log graphs is essential for the subsequent determination of different radioactive ranges that are used to establish the different radioactive maps accordingly. Each determined radioactive range for $(\mathrm{TC}, \mathrm{eU}$, eTh, and $\mathrm{K} \%$ ) reflects a specific geology as documented and discussed in this paper. Each available original radioactive map (TC, eU, eTh, and $\mathrm{K} \%$ ) is separately treated and interpreted by the $\mathrm{C}-\mathrm{N}$ technique as described above.

The different results obtained in this paper by applying the fractal C$\mathrm{N}$ modelling technique are therefore original and new in comparison with those already obtained by application of the SFAT technique (Asfahani et al., 2018). 


\section{Conclusion}

The C-N fractal modelling technique is applied in this paper to interpret the aerial gamma-ray spectrometric data of Area-2 in Syria. Different radioactive ranges of $\mathrm{TC}$, eU, eTh, and $\mathrm{K}$ have been isolated, and used to characterize the lithological outcrops in the study area. The radioactive signatures of all the outcrops in Area-2 have been determined and geologically interpreted through establishing the C-N maps of TC, eU, eTh, and $\mathrm{K}$. The radioactive break points accurately and precisely determined in this paper by the $\mathrm{C}-\mathrm{N}$ model efficacy serve as lithological boundaries between different kinds of rocks, and indicate the passage from a specific lithology to another different one. The new different derived radioactive ranges of (TC, eU, eTh, and $\mathrm{K}$ ) obtained by the $\mathrm{C}-\mathrm{N}$ technique reflect each a specific geology as documented and discussed in this paper. Those ranges will be used as a helpful tool and a smart guide for sampling rocks and for future detailed geological exploration surveys in the study area. The obvious role of the airborne gamma-ray spectrometric and fractal modelling techniques in geological mapping is demonstrated herein through the case study presented in this paper. Those two techniques support the geological mapping and the interpretations in geological context, particularly when the study region is rugged and difficult to be accessed. The acquired knowledge of this paper will be potentially employed later, when detailed geological and geochemical mining investigations are lanced for radiometric and other useful elements prospecting.

Acknowledgements. With a courteous permission of Dr. I. Othman, General Director of Syrian Atomic Energy Commission to publish this paper and thanks to the anonymous reviewers and the editorial board of CGG journal for their critics, remarks and suggestions they have considerably improved the final version of this paper. As well as thank you belongs to Dr. Igor Kohút, the technical editor of CGG for his collaboration during the handling of this paper.

\section{References}

Afzal P., Khakzad A., Moarefvand P., Rashidnejad Omran N., Esfandiari B., Fadakar Alghalandis Y., 2010: Geochemical anomaly separation by multifractal modeling in Kahang (Gor Gor) porphyry system, Central Iran. J. Geochem. Explor., 104, 1-2, 34-46, doi: 10.1016/j.gexplo.2009.11.003. 
Afzal P., Fadakar Alghalandis Y., Khakzad A., Moarefvand P., Rashidnejad Omran N., 2011: Delineation of mineralization zones in porphyry $\mathrm{Cu}$ deposits by fractal concentration-volume modeling. J. Geochem. Explor., 108, 3, 220-232, doi: 10.10 $16 / j$.gexplo.2011.03.005.

Afzal P., Zia Zarifi A., Bijan Yasrebi A., 2012: Identification of uranium targets based on airborne radiometric data analysis by using multifractal modeling, Tark and Avanligh 1:50000 sheets, NW Iran. Nonlinear Process. Geophys., 19, 283-289, doi : $10.5194 / \mathrm{npg}-19-283-2012$.

Afzal P., Dadashzadeh Ahari H., Rashidnejad Omran N., Aliyari F., 2013: Delineation of gold mineralized zones using concentration-volume fractal model in Qolqoleh gold deposit, NW Iran. Ore Geol. Rev., 55, 125-133, doi: 10.1016/j.oregeorev.2013 .05 .005 .

Afzal P., Mirzaei M., Yousefi M., Adib A., Khalajmasoumi M., Zia Zarifi A., Foster P., Yasrebi A. B., 2016: Delineation of geochemical anomalies based on stream sediment data utilizing fractal modeling and staged factor analysis. J. Afr. Earth Sci., 119, 139-149, doi: 10.1016/j.jafrearsci.2016.03.009.

Afzal P., Ahmadi K., Rahbar K., 2017a: Application of fractal-wavelet analysis for separation of geochemical anomalies. J. Afr. Earth Sci., 128, 27-36, doi : 10.1016/j.jafr earsci.2016.08.017.

Afzal P., Heidari S M., Ghaderi M., Yasrebi A. B., 2017b: Determination of mineralization stages using correlation between geochemical fractal modeling and geological data in Arabshah sedimentary rock-hosted epithermal gold deposit, NW Iran. Ore Geol. Rev., 91, 278-295, doi: 10.1016/j.oregeorev. 2017.09.021.

Asfahani J., 2017: Fractal theory modeling for interpreting nuclear and electrical well logging data and establishing lithological cross section in basaltic environment (case study from southern Syria). Appl. Radiat. Isot., 123, 26-31, doi: 10.1016/j .aprad iso. 2017.02 .020 .

Asfahani J., 2018a: Multifractal approach for delineating uranium anomalies related to phosphatic deposits in Area-3, Northern Palmyrides, Syria. Applied Radiation and Isotopes, 137, 225-235, doi: 10.1016/j.apradiso.2018.03.012.

Asfahani J., 2018b: Estimating and mapping radioactive heat production by using aerial spectrometric gamma and fractal modeling techniques in Syrian desert (Area-1), Syria. Appl. Radiat. Isot., 142, 194-202, doi : 10.1016/j.apradiso.2018.09.004.

Asfahani J., Al-Hent R., Aissa M., 2018: Radioactive characterization of Ar-Rassafeh Badyieh area (Area-2), Syria by using statistical factor analysis technique. Contrib. Geophys. Geod., 48, 2, 113-132, doi: 10.2478/congeo-2018-0004.

Carranza E. J. M., 2008: Geochemical anomaly and mineral prospectivity mapping in GIS, handbook of exploration and environmental geochemistry. Vol. 11, Elsevier, Amsterdam, 368 p., eBook ISBN: 9780080930312, hardcover ISBN: 9780444513250.

Cheng Q., Agterberg F. P., Ballantyne S. B., 1994: The separation of geochemical anomalies from background by fractal methods. J. Geochem. Explor., 51, 2, 109-130, doi: 10.1016/0375-6742(94)90013-2.

Cheng Q., Xu Y., Grunsky E., 1999: Integrated spatial and spectral analysis for geochemical anomaly separation. In: Lippard S. J., Naess A., Sinding-Larsen R., (Eds.): 
Proc. of the Fifth Annual Conference of the International Association for Mathematical Geology, Trondheim, Norway, 6-11th August 1999, Vol. 1, 87-92.

Cheng Q., 2007: Multifractal imaging filtering and decomposition methods in space, Fourier frequency, and eigen domains. Nonlinear Process. Geophys., 14, 3, 293303, doi: $10.5194 / \mathrm{npg}-14-293-2007$.

Davis J. C., 2002: Statistics and data analysis in geology, 3rd ed. John Wiley \& Sons Inc., New York, 656 p.

Dickson B. L., Scott K. M., 1997: Interpretation of aerial gamma ray surveys-adding the geochemical factors. AGSO J. Aust. Geol. Geophys., 17, 2, 187-200.

Jubeli Y. M., 1990: Uranium exploration in Syria SY/86/005, Final report; Atomic Energy Commission of Syria, Damascus.

Hassanpour S., Afzal P., 2013: Application of concentration-number (C-N) multifractal modelling for geochemical anomaly separation in Haftcheshmeh porphyry system, NW Iran. Arab. J. Geosci., 6, 3, 957-970, doi: 10.1007/s12517-011-0396-2.

Heidari S. M., Ghaderi M., Afzal P., 2013: Delineating mineralized phases based on lithogeochemical data using multifractal model in Touzlar epithermal $\mathrm{Au}-\mathrm{Ag}(\mathrm{Cu})$ deposit, NW Iran. Appl. Geochem., 31, 119-132, doi: 10.1016/j.apgeochem.2012. 12.014.

Hosseini S. A., Afzal P., Sadeghi B., Sharmad T., Shahrokhi S. V., Farhadinejad T., 2015: Prospection of $\mathrm{Au}$ mineralization based on stream sediments and lithogeochemical data using multifractal modeling in Alut 1:100,000 sheets, NW Iran. Arab. J. Geosci., 8, 6, 3867-3879 doi: 10.1007/s12517-014-1436-5.

International Atomic Energy Agency, 1988: Geochemical exploration for uranium. Technical Report Series 284, IAEA, Vienna, $97 \mathrm{p}$.

Li C., Ma T., Shi J., 2003: Application of a fractal method relating concentrations and distances for separation of geochemical anomalies from background. J. Geochem. Explor., 77, 2-3, 167-175, doi: 10.1016/S0375-6742(02)00276-5.

Mandelbrot B. B., 1983: The Fractal Geometry of Nature, W. H. Freeman, San Francisco, $468 \mathrm{pp}$.

Meigoony M. S., Afzal P., Gholinejad M., Yasrebi A. B., Sadeghi B., 2014: Delineation of geochemical anomalies using factor analysis and multifractal modeling based on stream sediments data in Sarajeh 1:100,000 sheet, Central Iran. Arab. J. Geosci., 7, 12, 5333-5343, doi: 10.1007/s12517-013-1074-3.

Mohammadi A., Khakzad A., Rashidnejad Omran N., Mahvi M. R., Moarefvand P., Afzal P., 2013: Application of number-size (N-S) fractal model for separation of mineralized zones in Dareh-Ashki gold deposit, Muteh Complex, Central Iran. Arab. J. Geosci., 6, 11, 4387-4398, doi : 10.1007/s12517-012-0662-y.

Nazarpour A., Omran N. R., Paydar G. R., 2015: Application of multifractal models to identify geochemical anomalies in Zarshuran Au deposit, NW Iran. Arab. J. Geosci., 8, 2, 877-889, doi : 10.1007/s12517-013-1183-z.

Rahmati A., Afzal P., Abrishamifar S. A., Sadeghi B., 2015: Application of concentrationnumber and concentration-volume fractal models to delineate mineralized zones in the Sheytoor iron deposit, Central Iran. Arab. J. Geosci., 8, 5, 2953-2965, doi : $10.1007 / \mathrm{s} 12517-014-1330-1$. 
Rafiee A., 2005: Separating geochemical anomalies in stream sediment media by applying combination of fractal concentration area model and multivariate analysis (Case study: Jeal-e-Barez 1:100,000 Sheet,Iran), 20th World Mining Congress Proceeding, Iran, 461-470.

Reimann C., Filzmoser P., Garrett R. G., 2005: Background and threshold: critical comparison of methods of determination. Sci. Total Environ., 346, 1-3, 1-16, doi: $10.1016 /$ j.scitotenv.2004.11.023.

Ris $\varnothing$, 1987: Aerial gamma-ray survey in Syria. Uranium exploration in Syria. SYR/87/005, Technical report, Risø DTU National Laboratory for Sustainable Energy, Roskilde, Denmark.

Sadeghi B., Moarefvand P., Afzal P., Yasrebi A. B., Saein L. D., 2012: Application of fractal models to outline mineralized zones in the Zaghia iron ore deposit, Central Iran. J. Geochem. Explor., Special Issue "Fractal/Multifractal Modelling of Geochemical Data", 122, 9-19, doi: 10.1016/j.gexplo.2012.04.011.

Saunders D. F., Branch J. F., Thomson C. K., 1994: Tests of Australian aerial radiometric data for use in petroleum reconnaissance. Geophysics, 59, 3, 411-419, doi: 10.1190/1.1443603.

Selley R. C., 1998: Elements of petroleum geology, 2nd ed. Book, Academic Press, chapter 3: Methods of exploration.

Wang Z., Cheng Q., Xu D., Dong Y., 2008: Fractal modeling of sphalerite banding in Jinding Pb-Zn deposit, Yunnan, Southwestern. China. J. China Univ. Geosci., 19, 1, 77-84, doi: 10.1016/S1002-0705(08)60027-8.

Wang Q. F., Deng J., Liu H., Wang Y., Sun X., Wan L., 2011: Fractal models for estimating local reserves with different mineralization qualities and spatial variations. J. Geochem. Explor., 108, 3, 196-208, doi: 10.1016/j.gexplo.2011.02.008.

Zuo R., 2011: Decomposing of mixed pattern of arsenic using fractal model in Gangdese belt, Tibet, China. Appl. Geochem., 26, Supplement, S271-S273, doi: 10.1016/j . apgeochem.2011.03.122. 